\title{
Peningkatan Kemampuan Pedagogik Guru melalui Program Pelatihan dan Pendampingan Bekelanjutan dalam Pembelajaran Computational Thinking pada Mata Pelajaran Matematika
}

\author{
Dyah Susilowati $^{1}$, Apriani $^{2}$, Kartarina Agustin $^{3}$, Ni Gusti Ayu Dasriani ${ }^{4}$ \\ dyah.susilowati@@universitasbumigora.ac.id ${ }^{1}$, 4priani@universitasbumigora.ac.id ${ }^{2}$, \\ Kartarina@universitasbumigora.ac.id ${ }^{3}$, ayu.areyu@universitasbumigora.ac.id ${ }^{4}$
}

1,2,3,4 Universitas Bumigora

Article History:
Received:
Accepted:

Keywords: Computational Thinking, pedagogic skill, Mathematics

\begin{abstract}
The problem faced by target partners (target schools) is the low ability of students to solve problems. In fact, problem solving ability is one of the skills that must be possessed in the 21 st century. This community service aims to improve teacher pedagogical competence in implementing Computational Thinking learning as well as assistance in its implementation. The method used is an educational approach with stages, identification of target schools, socialization of activities, implementation, monitoring and evaluation. The result of this activity was an increase in teacher knowledge in computational thinking by 95\%, and teacher interest in applying computational thinking to subjects by $92 \%$. The conclusion of this activity is known that community service partners have increased their knowledge of problem solving methods using a computational thinking approach and can apply them in mathematics learning.
\end{abstract}

\section{Pendahuluan}

Salah satu keterampilan penting di abad 21 adalah kompetensi pemecahan masalah (Bellanca et al., 2010). Diyakini bahwa keterampilan pemecahan masalah dapat diterapkan di ruang kelas matematika. Dalam studi TIMSS, banyak negara memiliki kurikulum matematika untuk SD dan SMP yang mencakup pemecahan masalah. Pada tahun 2006 UNESCO sudah mencantumkan keterampilan matematika/numerasi sebagai salah satu penentu kemajuan suatu bangsa. Kemampuan numerasi yang baik merupakan proteksi terbaik terhadap angka pengangguran, penghasilan yang rendah dan kesehatan yang buruk (Schleicher, 2015). Keterampilan numerasi dibutuhkan dalam semua aspek kehidupan, baik di rumah, di pekerjaan maupun di masyarakat. Kemampuan literasi memberikan kontribusi yang nyata terhadap pertumbuhan sosial, ekonomi dan kesejahteraan bagi individu atau masyarakat. Dengan memiliki populasi yang dapat mengaplikasikan pemahaman matematika di dalam konteks ekonomi, teknik, sains, sosial dan bidang lainnya, daya saing ketenagakerjaan dan kesejahteraan ekonomi akan meningkat.

Saat ini kemampuan literasi pelajar Indonesia masih rendah. Hasil test (OECD, 2018) dan TIMSS (2016), dua organisaasi di bawah OECD (Organisation for Econimic Co- 


\section{ADMA}

Gurnal Pengabdian dan Pemberdayaan Masyarakat

operation and Development) menunjukkan bahwa Indonesia menduduki peringkat 72 dari 78 negara untuk kemampuan matematika, science, dan membaca. Nilai kemampuan matematika Indonesia yaitu 371 , berada dibawab nilai rata-rata dunia yaitu 487 . Data ini dapat menjadi acuan untuk mengeneralisasi kemampuan rata-rata pelajar Indonesia di bidang matematika (literasi numerasi) yang dikatagorikan rendah. Sehubungan dengan keterampilan abad ke-21 dan kerangka PISA baru 2021, kegiatan ini akan berfokus pada uppaya peningkatan kemampuan pemikiran komputasi pada guru di Nusa Tenggara Barat, khususnya Lombok Tengah. (Gadanidis et al., 2017) berpendapat bahwa pendidikan harus membahas pengetahuan computational thinking yang perlu dikembangkan oleh guru karena guru memainkan peran penting dalam mewujudkan pemikiran komputasi yang sukses

Computational thinking (Berpikir komputasi) merupakan pendekatan proses berpikir seseorang dalam memecahkan masalah dengan sistem komputasi. Computational thinking (CT) telah diperkenalkan oleh (Wing, 2016) sebagai sebuah cara berpikir yang dapat meningkatkan keterampilan memecahkan masalah dengan sistem komputasi. CT termasuk penyelesaian masalah, merancang system dan memahami perilaku manusia dengan mengambarkan konsep dasar kedalam computer science. Selanjutnya (Wing, 2010) mendefinisikan lagi Computational Thinking sebagai proses berpikir yang diperlukan dalam memformulasikan masalah dan solusinya, sehingga solusi tersebut dapat menjadi agen pemroses informasi yang efektif dalam menyelesaikan masalah. Dua aspek fokus dalam definisi tersebut adalah pertama Computational thinking merupakan proses pemikiran, yang terlepas dari teknologi. Kedua, Computational thinking adalah metode penyelesaian masalah yang dirancang untuk dapat selesaikan dan dijalankan oleh manusia, komputer atau kedua-duanya. Dari berbagai paparan tentang computational thinking, dapat diketahui bahwa berpikir komputasi tidak hanya dapat dikenalkan dan d ikembangkan oleh pelajaran komputer atau pemrograman, tetapi dapat diterapkan dalam berbagai disiplin ilmu. Salah satunya adalah dalam pembelajaran matematika.

Saat ini guru-guru Madrasah Ibtidaiyah dan Madrasah Tsanawiyah di kabupaten Lombok Tengah belum mengenal pembelajaran computational thinking sehingga belum bisa mengajarkan kepada siswanya cara berpikir komputasi sebagai pendekatan untuk menyelesaikan persoalan dalam bidang matematika. Hal ini dikuatkan oleh hasil kuesioner yang disebarkan pada guru-guru MI dan MTs Lombok tengah yang menyatakan bahwa 100 $\%$ responden menyatakan belum mengenal tentang berpikir komputasi (computational thinking) baik dari contoh soal ataupun mengimplementasikan ke mata pelajaran.. Mengingat tuntutan ketrampilan abad 21, dimana kemampuan pemecahan masalah merupakan salah satu kemampuan yang harus dimiliki siswa, oleh karena itu hal ini harus segera diatasi dengan meningkatkan kemampuan pedagogik guru dalam pembelajaran computational thinking ini. Untuk mengatasi permasalahan yang terjadi saat ini, maka https://journal.universitasbumigora.ac.id/index.php/ADMA 
ADMA

Gurnal Pengabdian dan Pemberdayaan Masyarakat

diperlukan pelatihan berpikir komputasi (computational thinking) bagi guru, sehingga setelah mendapatkan pelatihan ini , guru dapat mengimplementasikan pembelajran computational thinking pada mata pelajaran yang diampunya. Pada kegiatan pengabdian masyarakat kali ini di fokuskan pemabahasan terkait cara mengintegrasikan/menginfus pembelajaran computational thinking dalam mata pelajaran matematika.

\section{Metode}

Tahap pelaksanaan kegiatan pengabdian masyarakat ini antara lain : tahap identifikasi sekolah sasaran, tahap sosialisasi program, tahap implementasi, tahap monitoring dan evaluasi. Rincian kegiatan yang dilakukan pada masing-masing tahap kegiatan dijelaskan sebagai berikut :

a. Tahap identifikasi sekolah sasaran : pada tahap ini tim pengabdian pada masyarakat melakukan koordinasi dengan pihak terkait pemerintah dalam hal ini dinas pendidikan kebudayaan dan atau yayasan sebagai badan penyelenggara pendidikan. Koordinasi dilakukan untuk mengidentifikasi sekolah sasaran yang bersedia dan memenuhi kriteria untuk mengikuti kegiatan pelatihan dan pendampingan untuk guru dan siswa tentang pembelajaran computational thinking (berfikir komputasi). Selanjutnya pihak dinas ataupun yayasan menginformasikan data sekolah dan guru yang siap memengikuti pelatihan dan pendampingan oleh tim pengabdian pada masyarakat Bebras Biro Universitas Bumigora

Tabel. 1 Daftar MI Peserta Sosialisasi Computational Thinking 3 September 2020

\begin{tabular}{clc}
\hline No & \multicolumn{1}{c}{ Nama Sekolah SD/MI } & $\begin{array}{c}\text { Jumlah } \\
\text { Guru }\end{array}$ \\
\hline 1 & Mi Nurul litihad Al Ma'arif Nu Lenser Kuta & 1 \\
2 & Mi Darul Abror Nw Rangkep Kuta & 8 \\
3 & Mis Darul Hikmah Darek & 5 \\
4 & Mi Nurul Iman Nw Pengembur & 2 \\
5 & Mi Raudlatul Jannah Nw Perempung & 3 \\
6 & Itihadul Ikhlas & 1 \\
\hline & Jumlah & $\mathbf{2 0}$
\end{tabular}




\section{ADMA}

Gurnal Pengabdian dan Pemberdayaan Masyarakat
2021, Vol.1, No.2, Hal. 125-134

Doi: 10.30812/adma.v1i2.1015

Tabel. 2 Daftar MTs Peserta Sosialisasi Computational Thinking 3 September 2020

\begin{tabular}{clc}
\hline No & \multicolumn{1}{c}{ Nama Sekolah SMP/Mts } & $\begin{array}{c}\text { Jumlah } \\
\text { Guru }\end{array}$ \\
\hline 1 & Mas Manhalul Ulum Praya & 1 \\
2 & Kb Rusyidah Al Ibrahimy Nw & 1 \\
3 & Mtss Sa Darul Abror & 7 \\
4 & Mts Darul Aminin Nw Aikmual & 6 \\
5 & Mtss Darul Hikmah Darek & 4 \\
6 & Mts Darul Masakin Karang Lebah & 3 \\
7 & Mts Manhalul Ulum Praya & 5 \\
8 & Mts Miftahul Ali & 6 \\
9 & Mts Miftahul Iman Nw Bundua & 1 \\
10 & Mtss Nurul ljtihad Nu Lenser & 1 \\
11 & Mtss NURUL IMAN NW KERUAK & 3 \\
12 & Mts Nurul Yaqin Praya & 4 \\
13 & Mtss Nurul Iman Nw Pengembur & 2 \\
14 & Mts Nw Sanggeng & 2 \\
15 & Mts Raudlatul Jannah Nw Perempung & 2 \\
16 & Mts Sa'adatuddarain Wakan & 8 \\
17 & Mts Ulil Absor Panti Jago & 4 \\
18 & Mts Nurul ljtihad Al Ma'arif Nu Lenser Kuta & 1 \\
19 & Mts Raudlatul Jannah Nw Perempung & 1 \\
20 & Mts Manhalul Ulum Praya & 1 \\
21 & Smp Islam Minhajussalam Nw Manggong & 2 \\
22 & Smp Islam Rusydah Nw Sengkol li & 2 \\
\hline \multicolumn{2}{r}{ Jumlah } & 67 \\
\hline
\end{tabular}

b. Melakukan kegiatan Sosialisasi

Kegiatan sosialisasi dilakukan untuk memberikan wawasan pengetahuan pada guru atau pengelola sekolah tentang pentingnya ketrampilan abad 21 dan pembelajaran berpikir komputasi (computational thinking) bagi siswa agar memiliki keterampilan memecahkan masalah dan berfikir kritis

c. Implementasi kegiatan pelatihan dan pendampingan pada guru dan siswa

Pada tahap ini dilakukan kegiatan pelatihan dan pendampingan pada guru-guru dalam menginfus computational thinking pada mata pelajaran yang diampunya, khususnya mata pelajaran Matematika bagi guru MTs dan cara menerapkan computational thinking dalam bingkai tematik untuk guru sekolah dasar atau Madrasah Ibtidaiyah (MI).

d. Monitoring dan Evaluasi

Pada tahap ini dilakukan monitoring oleh tim pengabdian masyarakat secaa periodik yaitu setiap 2-3 bulan sekali untuk mengetahui capaian, kendala yang dihadapi guru pada saat mengimplementasikan pemelajaran computational thinking pada siswa serta mencari solusi atas permasalahan yang terjadi. Sedangkan evalusi dilakukan di 


\section{ADMA}

Gurnal Pengabdian dan Pemberdayaan Masyarakat

akhir kegiatan pengabdian masyarakat oleh tim pengabdian masyarakat bebras Biro UBG, kepala sekolah an pihak dinas terkait untuk mengevaluasi ketercapaian program sesuai indicator yang ditetapkan.

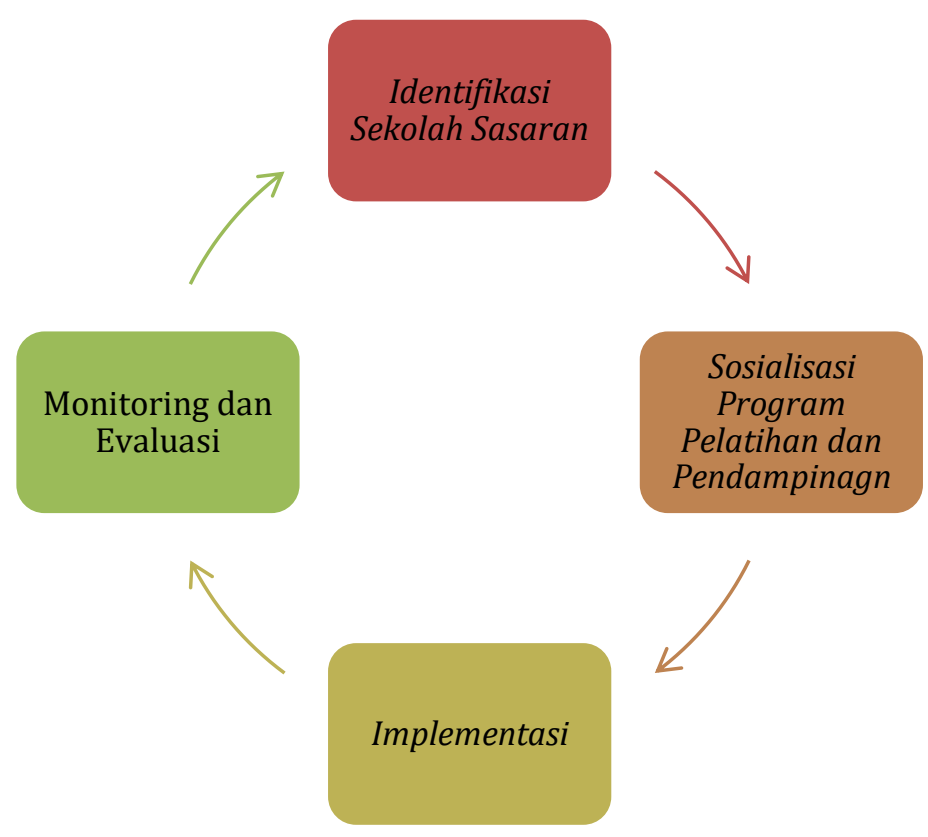

Gambar 1. Metode pengabdian pada masyarakat

\section{Pembahasan}

Dalam kegiatan pengabdian masyarakat ini dilakukan program pelatihan/workshop pada guru maupun siswa tentang computational thinking, pengenalan web Olympia yang berisi tentang berbagai latihan soal computational thinking, pendampingan pada siswa untuk persiapan bebras challenge dan pemantauan peserta lomba saat pelaksanaan lomba bebras challenge. Transfer pengetahuan terkait computational thingking yang dilakukan pada program pengabdian mesyarakat kali ini adalah mengajarkan metode atau sintak pembelajaran tentang bagaimana mengimplementasikan computational thinking ke dalam mata pelajaran matematika. Berikut ini dijelaskan tahapan penerapan yang dilakukan: 


\section{ADMA}

Gurnal Pengabdian dan Pemberdayaan Masyarakat
2021, Vol.1, No.2, Hal. 125-134

Doi: 10.30812/adma.v1i2.1015

Tabel 3. Elemen Computational Thinking

\begin{tabular}{|l|l|lr|}
\hline Tahap & Elemen CT & Uraian \\
\hline I & Abstraksi & $\begin{array}{l}\text { Mengeneralisasi makna } \\
\text { soal }\end{array}$ \\
\hline II & Dekomposisi & $\begin{array}{l}\text { Memecah persoalan } \\
\text { kompleks menjadi sub } \\
\text { bagian } \\
\text { kecilsehingga rebibi } \\
\text { dikelola } \\
\text { menyelesaiakan } \\
\text { keseluruhan }\end{array}$ \\
\hline III & Pengenalan Pola \\
\hline IV & Algoritma & $\begin{array}{l}\text { Mengenali pola yang ada } \\
\text { dalam soal }\end{array}$ \\
\hline
\end{tabular}

Salah satu contoh bagaimaa menerapkan atau menginfus computational thinking dalam mata pelajaran matematika dapat dilakukan dengan merancang soal berbasis problem solving sebagai berikut: Jarak rumah Tita ke sekolah $1 \mathrm{Km}$, sedangkan jarak rumah Ali ke sekolah adalah $3 \mathrm{Km}$. Waktu yang diperlukan Tita ke sekolah dengan berjalan kaki yaitu selama 10 menit. Jika Ali berangkat ke sekolah pukul 06.00, jam berapa Ali sampai ke sekolah?

Ayo Membaca!

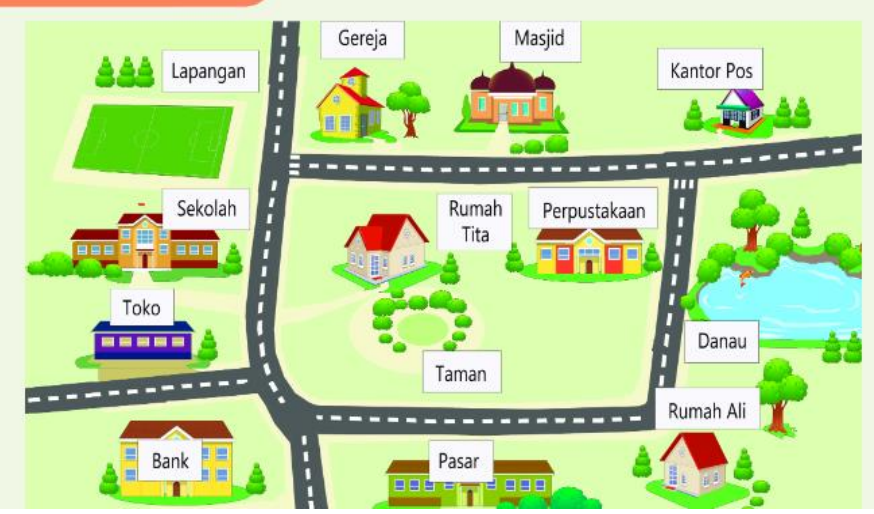

Gambar 2. Soal CT Matematika

Analisa Computational Thinking sebagai berikut :

a Abstraksi : Menghitung waktu

Dekomposisi : Jarak dan waktu dari rumah ke sekolah

- Pengenalan Pola : perkalian, penjumlahan 


\section{ADMA}

Gurnal Pengabdian dan Pemberdayaan Masyarakat
2021, Vol.1, No.2, Hal. 125-134

Doi: 10.30812/adma.v1i2.1015

a Algoritma

: Langkah-langkah untuk menghitung waktu yang dibutuhkan untuk menempuk jarak dari rumah ke sekolah

1. Jika untuk menempuh jarak $1 \mathrm{~km}$ dibutuhkan waktu 10 menit

2. Hitung waktu untuk menempuh jarak $3 \mathrm{~km}$ ( $3 \times 10$ menit $=30$ menit)

3. Hitung waktu yang dibutuhkan Ali untuk menuju ke sekolah. (berangkat jam $06.00+30$ menit $=06.30$ )

Berikut dokumentasi kegiatan pengabdian.
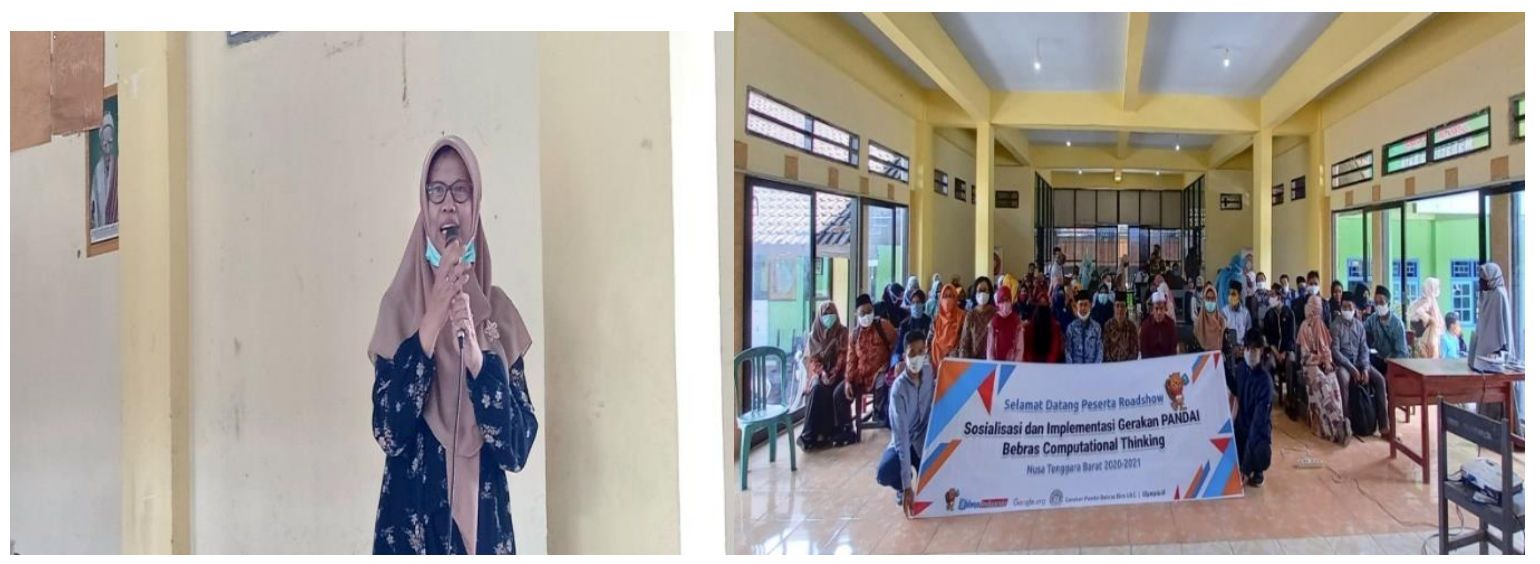

Gambar 3.Kegiatan Sosialisasi
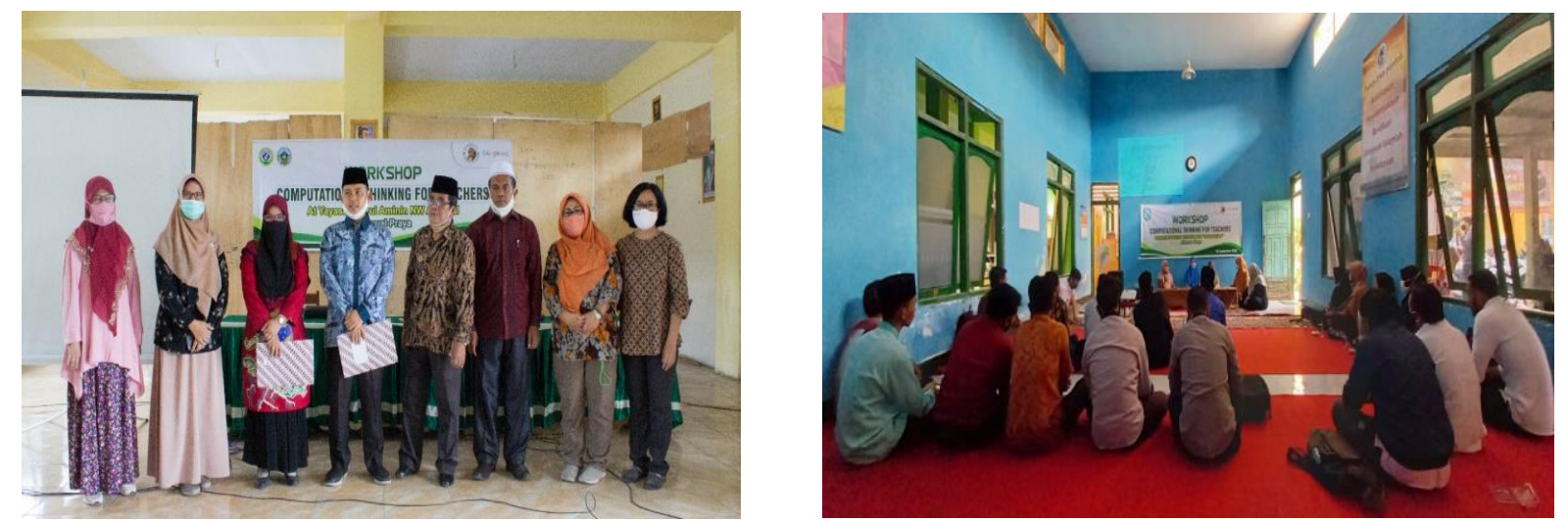

Gambar. 4. Workshop Computational Thinking

Hasil yang diperoleh dari pelatihan/workshop computational thinking adalah peningkatan pengetahuan peserta serta adanya ketertarikan guru dalam menerapkan computational thinking dalam mata pelajaran yang diampunya. Pada akhir kegiatan ini, dilakukan evaluasi dengan menyebarkan kuesioner. Dari pengumpulan data yang dilakukan pada akhir kegiatan dapat diketahui bahwa mitra sasaran (guru) yang sangat memahami Computational thinking sebayak $59 \%$, dan guru yang memahami sebanyak $36 \%$. Sedangkan yang kurang memahami sebanyak $3 \%$ dan tidak memahami sebanyak $2 \%$. Dari hasil tersebut dikisimpulkan bahwa sebagian besar peserta dapat mencapai pemahaman materi pelatihan sehingga diharapkan dapat melakukan implementasi atau menginfus compational thinking https://journal.universitasbumigora.ac.id/index.php/ADMA 


\section{ADMA}

Gurnal Pengabdian dan Pemberdayaan Masyarakat
2021, Vol.1, No.2, Hal. 125-134

Doi: 10.30812/adma.v1i2.1015

ke dalam mata pelajaran yang diampu. Masih adanya peserta yang belum memahami materi pelatihan sebanyak $5 \%$, mungkin disebabkan karena terdapat peserta yang terlambat hadir sehingga peserta yang terlambat tersebut tidak dapat memperoleh penjelasan materi pelatihan secara lengkap. Ilustrasi dapat dilihat pada gambar 5 .

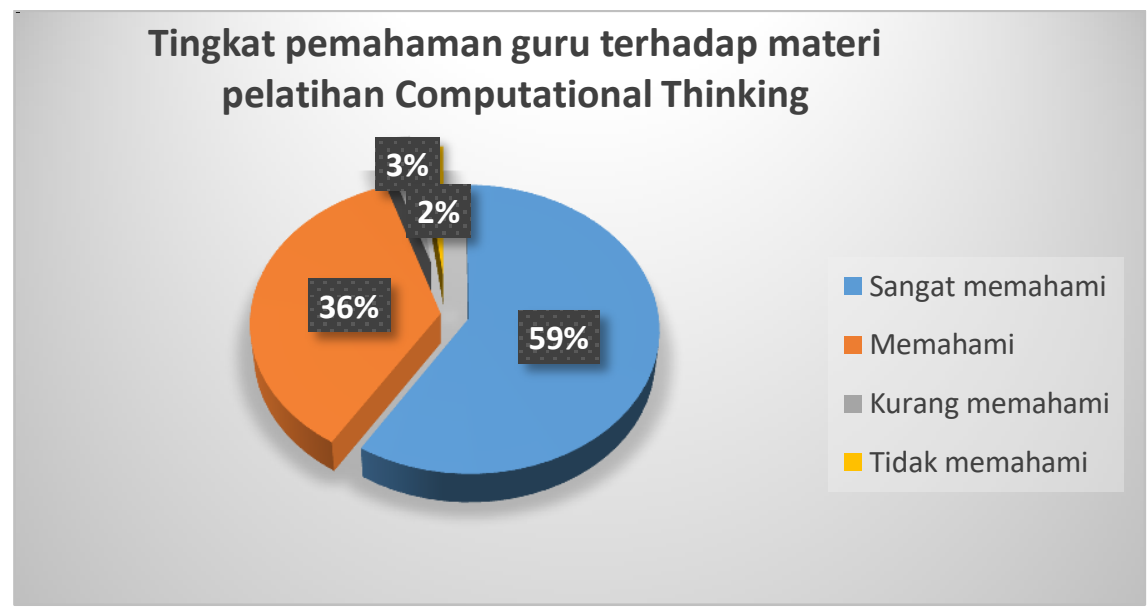

Gambar 5.Tingkat pemahaman guru terhadap materi Computational Thinking

Sedangkan mitra sasaran yang menyatakan bahwa mereka tertarik untuk menerapkan computational thinking yaitu sebanyak $66 \%$ guru menyatakan sangat setuju, dan guru yang menyatakan setuju sebanyak $26 \%$. Sedangkan $3 \%$ guru menyatakan tidak setuju dan sebayak $5 \%$ guru netral. Dari hasil tersebut dapat diketahui bahwa sebagian guru/ mitra sasaran kegiatan pengabdian masyarakat ini menyatakan tertarik untuk menerapkan computational thinking pada mata pelajaran yang diampunya. Ilustrasi dapat dilihat pada gambar 4.

\section{Tingkat ketertarikan Guru dalam menerapkan}

Computational Thinking pada mata pelajaran

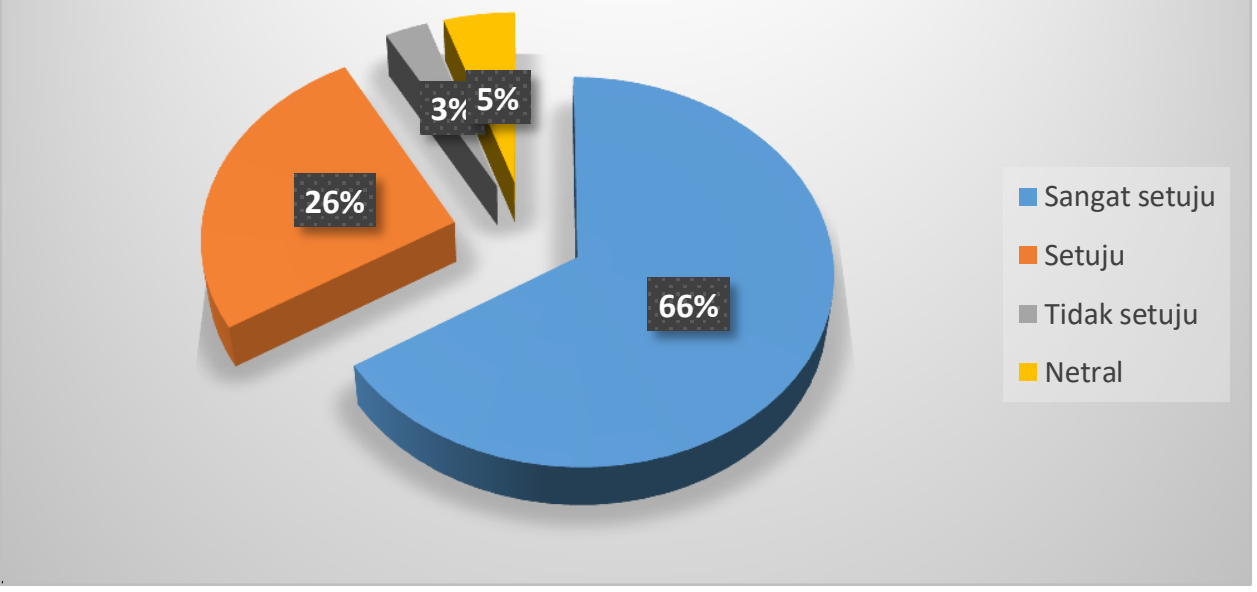

Gambar 6 Tingkat ketertarikan Guru dalam menerapkan Computational Thinking 
Dengan peningkatan pengetahuan guru dalam computational thinking dan tingginya motivasi/ketertarikan mereka dalam menerapkan computational thinking daam pembelajaran khususnya mata pelajaran matematikan diharapkan dapat menjadi terobosan baru dalam meningkatkan keterampilan siswa dalam memecahkan masalah. Dalam jangka panjang diharapkan dapat meningkatkan nilai PISA siswa Indonesia khususnya dalam linerasi numerasi. Hal ini sejalan dengan studi sebelumnya bahawa mengintegrasikan pemikiran komputasi dan pemikiran matematika memperdalam konsep matematika siswa (Ho, Looi, Huang, Looi, \& Longanathan, 2018). Prinsip desain dan implementasi kelas dari pemikiran komputasi telah dianalisis dalam konteks Singapura (Ho, Looi, Huang, Seow, \& Wu, 2019).

\section{Kesimpulan}

Kesimpulan yang dapat diambil dari kegiatan ini adalah :

1. Peserta dari mitra pengabdian kepada masyarakat meningkat pengetahuannya tentang metode pemecahan masalah menggunakan pendekatan computational thinking.

2. Peserta dari mitra pengabdian kepada masyarakat termotivasi/tertarik menerapkan computational thinking pada mata pelajaran yang mereka ampu.

3. Peserta dari mitra pengabdian kepada masyarakat dapat menerapkan ilmu yang diperoleh, untuk merancang soal matematika /literasi numerasi yang dikaitkan dengan problem nyata yang terjadi sehari-hari.

Kesimpulan tersebut sekaligus menunjukkan dampak pengabdian kepada masyarakat secara langsung kepada sasaran/peserta kegiatan.

\section{Ucapan Terimakasih}

Ucapan terimakasih kami ucapkan kepada semua pihak yang telah mendukung lancarnya kegiatan pengabdian masyarakat ini antara lain : Universitas Bumigora, LPPM UBG, Ketua Bebras Biro NTB, pihak sekolah SD, SMP, MI, MTS yang telah berpartisipasi dalam kegiatan ini, serta seluruh tim Bebras Biro UBG baik dosen maupun mahasiswa.

\section{Daftar Pustaka}

Bellanca, B. J., Eds, R. B., Barell, J., Darling-hammond, L., Dede, C., Dufour, R., Dufour, R., Fisher, D., Fogarty, R., Frey, N., Gardner, H., Hargreaves, A., David, W., Johnson, R. T., Kay, K., Lemke, C., Mctighe, J., \& November, A. (2010). 21st Century Skills: Rethinking How Students Learn. Solution Tree Press.

Gadanidis, G., Cendros, R., \& Floyd, L. (2017). Computational Thinking in Mathematics Teacher Education. Contemporary Issues in Technology and Teacher Education, 17, 458-477.

OECD. (2018). Indonesia What 15-year-old students in Indonesia know and can do. Programme for 


\section{ADMA}

Gurnal Pengabdian dan Pemberdayaan Masyarakat

International Student Assessment (PISA).

Schleicher. (2015). Schools for 21st-Century Learners Strong Leaders, Confident Teachers, Innovative Approaches. http://istp2015.org/Documents/ISTP2015_OECD-background-report.pdf

Wing, J. M. (2010). Computational Thinking: What and Why? (Issue March 2006). https://www.cs.cmu.edu/link/research-notebook-computational-thinking-what-and-why

Wing, J. M. (2016). Computational Thinking. Communications of the ACM, 33-35(March 2006). https://doi.org/10.1145/1118178.1118215 